University of Nebraska - Lincoln

DigitalCommons@University of Nebraska - Lincoln

Agronomy \& Horticulture -- Faculty Publications

Agronomy and Horticulture Department

$1-31-2008$

\title{
Decomposition of Bt and Non-Bt Corn Hybrid Residues in the Field
}

David D. Tarkalson

United States Department of Agriculture, Agricultural Research Service, david.tarkalson@ars.usda.gov

Stephen D. Kachman

University of Nebraska-Lincoln, steve.kachman@unl.edu

Johannes M. H. Knops

University of Nebraska-Lincoln, jknops@unl.edu

Janice E. Thies

Cornell University

Charles S. Wortmann

University of Nebraska-Lincoln, cwortmann2@unl.edu

Follow this and additional works at: https://digitalcommons.unl.edu/agronomyfacpub

Part of the Plant Sciences Commons

Tarkalson, David D.; Kachman, Stephen D.; Knops, Johannes M. H.; Thies, Janice E.; and Wortmann, Charles S., "Decomposition of Bt and Non-Bt Corn Hybrid Residues in the Field" (2008). Agronomy \& Horticulture -- Faculty Publications. 131.

https://digitalcommons.unl.edu/agronomyfacpub/131

This Article is brought to you for free and open access by the Agronomy and Horticulture Department at DigitalCommons@University of Nebraska - Lincoln. It has been accepted for inclusion in Agronomy \& Horticulture -Faculty Publications by an authorized administrator of DigitalCommons@University of Nebraska - Lincoln. 


\title{
Decomposition of Bt and Non-Bt Corn Hybrid Residues in the Field
}

\author{
David D. Tarkalson · Stephen D. Kachman • \\ Johannes M. N. Knops · Janice E. Thies • \\ Charles S. Wortmann
}

Received: 8 May 2007/ Accepted: 21 August 2007/Published online: 11 September 2007

\begin{abstract}
Results of a previous laboratory study indicated that six transgenic crops expressing the $\mathrm{Cry} 1 \mathrm{Ab}$ insecticidal protein from Bacillus thuringiensis (Bt) decomposed at a slower rate than their respective non- $\mathrm{Bt}$ isolines. Consequently, litter decomposition rates, nitrogen cycling, and carbon pools may change in agricultural systems as the result of the widespread use of Bt crops. In this study, we assessed the decomposition rates and chemical composition of commonly grown hybrids
\end{abstract}

\section{D. Tarkalson $(\bowtie)$}

United States Department of Agriculture, Agricultural Research Service, Northwest Irrigation and Soils Research Laboratory, 3793 North 3600 East, 83341 Kimberly, ID, USA

e-mail: davidt@nwisrl.ars.usda.gov

\section{S. D. Kachman}

Department of Statistics, University of Nebraska-Lincoln, Lincoln, NE, USA

\section{J. M. N. Knops}

School of Biological Sciences, University

of Nebraska-Lincoln, Lincoln, NE, USA

\section{J. E. Thies}

Department of Crop and Soil Sciences,

Cornell University, Ithaca, NY, USA

\section{S. Wortmann}

Department of Agronomy and Horticulture, University

of Nebraska-Lincoln, Lincoln, NE, NE of $\mathrm{Bt}$ and non-Bt isolines of corn (Zea mays L.) in the field. Leaves, stalks, and cobs from two Bt corn hybrids (Pioneer 34N44 Bt and NC+ $4990 \mathrm{Bt}$ ) and their non-Bt isolines (Pioneer 34N43 and NC+ 4880) were analyzed for biomass fractions (soluble, hemicellulose, cellulose, and lignin) and total $\mathrm{C}$ and $\mathrm{N}$ content. Litterbags containing these residues were buried at a depth of $10 \mathrm{~cm}$ in a Holdrege silt loam (fine-silty, mixed, mesic Typic Argiustolls) soil and recovered 5, 11, 17, and 23 months after placement in the field. There were no differences in the rates of decomposition and mass of $\mathrm{C}$ remaining over time between the $\mathrm{Bt}$ and non-Bt corn residues. Plant parts differed in decomposition rates where leaves $>$ stalks $>$ cobs. There were differences in total $\mathrm{C}$, total $\mathrm{N}$, biomass fractions, and $\mathrm{C}: \mathrm{N}$ ratios between initial $\mathrm{Bt}$ and non-Bt corn residues, and between companies (NC+ and Pioneer), however, these differences did not result in differences in their rates of decomposition or mass of $\mathrm{C}$ remaining over time. For each plant part, there were no differences in lignin content between the $\mathrm{Bt}$ and non-Bt residues. These data suggest that the $\mathrm{Bt}$ and nonBt corn hybrids used in this study should not cause differences in carbon sequestration when their residues decompose under similar environmental conditions.

Keywords Decomposition $\cdot \mathrm{Bt}$. Corn · Biomass - Biomass fraction · Lignin $\cdot$ Soluble $\cdot$ Cellulose $\cdot$ Hemicellulose 


\section{Abbreviations}

$\begin{array}{ll}\text { AFDW } & \text { Ash free dry weight } \\ \text { Bt corn } & \text { Corn hybrid containing insecticidal pro- } \\ & \text { teins derived from the bacterium, Bacillus } \\ & \text { thuringiensis }\end{array}$

ANOVA Analysis of variance

\section{Introduction}

Transgenic Bt corn expresses insecticidal proteins derived from the bacterium, Bacillus thuringiensis (Bt) (Schnepf et al. 1998). These proteins are toxic to lepidopteran pests that feed on corn. The Bt technology has prevented yield losses due to these pests and reduced the need for pesticide application (Flores et al. 2005). After the introduction of this technology, concerns were raised about the negative effects of $\mathrm{Bt}$ crop residues on the environment (Rissler and Mellon 1996; Flores et al. 2005) and on the fate of the Bt proteins in soil (Sims and Ream 1997; Stotzky 2000; Saxena et al. 2002; Saxena and Stotzky 2003). The effect of Bt technology on crop residue decomposition in soil has been studied, including the effects of $\mathrm{Bt}$ insecticidal proteins on populations of decomposing soil microbes (Saxena and Stotzky 2001a, b, c, 2002; Zwahlen et al. 2003; Blackwood and Buyer 2004; Devare et al. 2004; Wei-xang et al. 2004; Baumgarte and Tebbe 2005; Flores et al. 2005) and the effects of tissue composition of Bt compared with non-Bt crops on decomposition of residues (Saxena and Stotzky 2001c; Flores et al. 2005).

Most studies conducted to assess the effects of the insecticidal proteins on soil microbes and other organisms have concluded that these proteins do not significantly alter microbial populations and measured functions compared with microbial populations not exposed to the proteins. Devare et al. (2004) found that soils cropped to corn expressing the $\mathrm{Cry} 3 \mathrm{Bb}$ insecticidal protein for corn root worm protection did not change microbial activity, $\mathrm{N}$ mineralization potential, short-term nitrification, and soil respiration rate compared with soils cropped to the non-transgenic isoline. Baumgarte and Tebbe (2005) concluded that the Cry1 Ab insecticidal protein for corn borer control had less effect on the bacterial community structure than other environmental factors. Saxena and Stotzky (2001b) did not find any significant toxic effects of
Bt corn on earthworms, nematodes, protozoa, bacteria, and fungi compared to non-Bt corn.

In addition to the production of larvicidal proteins, Bt and non-Bt corn hybrids may differ in other ways. In laboratory research, plant residue of Bt hybrids decomposed at a slower rate in soil than non-Bt hybrids (Flores et al. 2005). However, Hopkins and Gregorich (2003) found no differences in $\mathrm{CO}_{2}$ production from $\mathrm{Bt}$ and non-Bt hybrids in soil over a 43-days incubation period. Variation in the biomass fractions of hybrids may influence rates of decomposition in soil. Saxena and Stotzky (2001c) showed that $\mathrm{Bt}$ hybrids contain a higher lignin content compared with near-isogenic non-Bt hybrids. Lignin are amorphous and highly branched molecules and contain high concentrations of aromatic compounds (Coyne 1999). The chemical bonds in these aromatic compounds are difficult to cleave and are more resistant to microbial decomposition than the bonds in hemicellulose and cellulose, which are more easily cleaved. The order of ease of decomposition of biomass fractions by soil microbes are starches $>$ hemicellulose $>$ cellulose $>$ lignin (Coyne 1999).

Many genetic and environmental factors can influence concentrations of lignin in corn and other plant species (Barriere et al. 2003; Motavalli et al. 2004; Prior et al. 2004). If residues from Bt compared with non-Bt corn differ in lignin content, this may have long-term implications on soil quality, soil microbial activities, and soil $\mathrm{C}$ sequestration. Reduced rates of residue decomposition and the associated accumulation of soil organic matter may increase soil productivity and improve soil ecological functions. Overall sequestration of $\mathrm{C}$ in agricultural soils may increase, thereby contributing to reduced global warming (Lal et al. 1998). However, only a limited number field studies have been published that assess the differences in residue decomposition between $\mathrm{Bt}$ and non-Bt corn hybrids in the field. One field study assessed differences in mass losses in the field between $\mathrm{Bt}$ and non-Bt cotton lines, and showed there were no differences over a period of 20 weeks (Lachnicht et al. 2004).

The hypothesis for this study was that Bt corn hybrid residues will decompose at a slower rate than their non-Bt isolines when buried in soil in the field due to differences in biomass fraction composition of the residues (Saxena and Stotzky 2001c). The objectives of this research were to: (1) Determine if residue 
from commonly grown Bt and non-Bt hybrids differ in rate of decomposition; (2) Determine if concentrations of biomass fractions, total $\mathrm{C}$, and $\mathrm{N}$ in crop residues differ between the hybrids; and (3) Determine if biomass fractions, and total $\mathrm{C}$ and $\mathrm{N}$ are related to rate of decomposition.

\section{Materials and methods}

Study site and corn hybrids

This field study was located at the University of Nebraska-Lincoln West Central Research and Extension Center in North Platte, NE. The soil at this site was a Holdrege silt loam (fine-silty, mixed, mesic Typic Argiustolls) with an organic carbon content of $18 \mathrm{~g} \mathrm{~kg}^{-1}$ and a $\mathrm{pH}$ of 6.5 in the surface $20 \mathrm{~cm}$. Treatments consist of two common, adapted Bt corn hybrids (Pioneer 34N44 Bt and NC+4990 Bt) and their non-Bt isolines (Pioneer 34N43 and NC+ 4880). Both Bt hybrids used in this study express the genes coding for the Cry1 $\mathrm{Ab}$ insecticidal protein and represent the MON810 transformation event. From 2003 to 2005, the hybrid treatments were planted in a ridge-till system in field plots $(4.6 \times 45.7 \mathrm{~m})$ in a randomized complete block design with four replications.

The plots were furrow-irrigated to meet $100 \%$ of crop evapotranspiration requirement. Soil samples were collected from the site in the spring of each year to determine nutrient needs based on the University of Nebraska recommendations. Nitrogen fertilizer was applied to match the University of Nebraska recommended rates of 202, 218, and $224 \mathrm{~kg} \mathrm{~N}^{-1}$ as ammonium nitrate in 2003, 2004, and 2005, respectively (Shapiro et al. 2003). The plants from the 2003 season were the source of the plant materials for the litter bag study (described below). The four hybrids continued to be planted in their respective plots in 2004 and 2005 to provide the environment for the litter bag study. The plots were cultivated each year at the V8 growth stage to clear residue and soil from the furrows to facilitate irrigation water movement and for weed control.

\section{Litter bag study}

The litter bag study was a complete factorial including three treatment factors, corn hybrid, plant part, and incubation time. The four corn hybrids used in the field study, Pioneer 34N44 Bt, Pioneer 34N43, NC+ $4990 \mathrm{Bt}$, and NC+4880, were used in this study too. The plant parts included cobs, leaves (blades only), and stalks (included leaf sheaths). The four incubation times were 5, 11, 17, and 23 months. Each treatment was replicated four times. The plant tissue characterization and the litter bag study were conducted using plant material from the 2003 field study only.

In October 2003, after the corn from each plot had reached physiological maturity, approximately 200 whole plants from each of four plots representing the four hybrids were removed from the field. The grain was removed from the cobs, and the cobs, stalks, and leaves were separated for each of the four hybrids. The plant parts were dried at $65^{\circ} \mathrm{C}$ to constant weight. Four subsamples from each hybrid and plant part (initial plant material) were ground and analyzed for total $\mathrm{C}$, total $\mathrm{N}$, and biomass fractions (soluble, hemicellulose, cellulose, and lignin). Biomass fractions were determined by sequential extraction following standard forage chemistry methods (Van Soest 1982). The first extraction (neutral detergent) removed cell contents, including soluble carbohydrates, lipids, pectin, starch, soluble protein, and nonprotein nitrogen (soluble fraction). The second fraction (acid detergent) removed hemicellulose and protein bound to cell walls (hemicellulose fraction). The third digestion $\left(72 \% \mathrm{H}_{2} \mathrm{SO}_{4}\right)$ hydrolyzed and removed cellulose (cellulose fraction), leaving lignin and related recalcitrant materials as the fourth and final fraction (lignin fraction). Although these fractions are referred to by their predominant biochemical components (e.g. cellulose, hemicellulose, lignin), these fractions are heterogeneous and not well defined biochemically (Van Soest 1982). Extractions were performed on $0.5 \mathrm{~g}$ plant samples placed in acid-resistant heat-sealed pouches, which were sequentially extracted in an Ankom Fiber Analyzer (Ankom Tech., Fairport, NY), with samples dried and reweighed after each step. The order of solubility of biomass fractions using this method followed the same order of ease of decomposition of these materials by soil microbes: starches (component of soluble fraction) $>$ hemicellulose $>$ cellulose $>$ lignin (Coyne 1999). Total C and $\mathrm{N}$ were determined using elemental combustion analysis with a Costech elemental analyzer (Model ECS 4010, Costech Analytical Technologies, Inc. Valencia, CA). The 
ash-free dry weight (AFDW) of the plant materials was determined by combusting approximately $0.5 \mathrm{~g}$ of sample at $500^{\circ} \mathrm{C}$ for $2.5 \mathrm{~h}$ in a muffle furnace.

Two pieces of square nylon netting material $(127 \mathrm{~mm} \times 127 \mathrm{~mm})$ with a mesh size of $0.79 \mathrm{~mm}$ were sown together on three sides with heavy-duty nylon thread. Approximately $10 \mathrm{~g}$ of air dried plant sample was placed in litter bags. The litter bags were weighted empty and again containing the plant material. The bags were closed at the top by folding the top $1.3 \mathrm{~cm}$ of the bag over and stapling four times. An aluminum tag with the bag ID etched into the aluminum was tied to each bag with copper wire. The litter bags were buried $15 \mathrm{~cm}$ from the corn row to a depth of $10 \mathrm{~cm}$ in the field plots on 5 December 2003. The litter bags were placed into the replicated field plots so the hybrids of the litter bags and field plots matched.

From each plot, one litter bag for each plant part was extracted on 5 May and 5 November 2004, and on 5 May and 5 November 2005. The litter bags were dried at $65^{\circ} \mathrm{C}$ to constant dry weight. The plant material and accompanying soil were removed from the nylon bags and the plant material and soil were weighed together. The plant with soil samples were ground, mixed, and subsamples from each sample weighing from $0.5 \mathrm{~g}$ to $0.9 \mathrm{~g}$ were placed into disposable aluminum trays and total weights recorded. The samples were placed in a muffle furnace and ashed at $500^{\circ} \mathrm{C}$ for $2.5 \mathrm{~h}$. The samples were allowed to cool, and the ash and aluminum trays were weighed to obtain an ash free dry weight. A correction was made for the AFDW of the initial plant materials. The AFDW data was used to determine the percent of plant material remaining $($ AFDW final/AFDW initial $\times 100$ ) (Lachnicht et al. 2004). Total $\mathrm{C}$ and $\mathrm{N}$ of the remaining plant residues were determined using elemental combustion analysis with a Costech elemental analyzer (Model ECS 4010, Costech Analytical Technologies, Inc. Valencia, CA). A post analysis correction using the plant/soil residue dry weight, the AFDW final weight, and the total $\mathrm{C}$ and $\mathrm{N}$ content of the soil was made to account for the soil in the residue samples.

\section{Data analysis}

The decomposition data for each plant part and hybrid were fitted using non-linear regression to the exponential decay model (Olsen 1963): $y=a e^{-k x}$

where $a$ is the original percent of the plant mass, $y$ is the predicted percent mass remaining after time $x, k$ is the decomposition constant $\left(\right.$ month $\left.^{-1}\right)$, and $x$ is the incubation period in months until the litter bag was extracted.

Analysis of variance (ANOVA) was conducted using the randomized complete block factorial model from Statistix 8 (Analytical Software 2003) to test the significance of hybrid and plant part main effects and two-way interactions for decomposition rate constants $(k)$. Within each plant part, an ANOVA was conducted to test effects of $\mathrm{Bt}$ (Bt versus non-Bt), company ( $\mathrm{NC}+$ versus Pioneer), and the $\mathrm{Bt} \times \mathrm{com}$ pany interaction for $k$.

Analysis of variance was conducted to test the significance of hybrid and plant part main effects and two-way interaction for total $\mathrm{C}$, total $\mathrm{N}$, biomass fractions (soluble, hemicellulose, cellulose, lignin), and $\mathrm{C}: \mathrm{N}$ ratios of the initial plant parts. Within each plant part, ANOVA was conducted to test effects of hybrid, Bt, company, and the two-way interaction for the total $\mathrm{C}$, total $\mathrm{N}$, biomass fractions, and $\mathrm{C}: \mathrm{N}$ ratios of the initial plant materials.

Analysis of variance was conducted using a splitplot in time model to test the effects of hybrid, plant part, extraction time, and interactions for total $\mathrm{C}$ and total $\mathrm{N}$ remaining in leaves, cobs, and stalks. Hybrid and plant part were the main plots and extraction time was the sub-plot in the model. Within each plant part, ANOVA was conducted to test effects of hybrid, Bt, company, extraction time, and the interactions for the total mass of $\mathrm{C}$ and total $\mathrm{N}$ remaining, and $\mathrm{C}: \mathrm{N}$ ratios.

Mean separations were done by the ANOVAprotected least significant difference (LSD) procedure. A significance level of 0.05 was used for all statistical analysis.

\section{Results and discussion}

Decomposition rate constants $(k)$ for leaves, cobs, and stalks were not different for $\mathrm{Bt}$ and non-Bt and for $\mathrm{NC}+$ and Pioneer hybrids. (Tables 1, 2; Fig. 1). These results are contrary to Saxena and Stotzky (2001c) and Flores et al. (2005) who found that Bt hybrids decomposed slower than non-Bt isolines when assessed using $\mathrm{CO}_{2}$ evolution techniques in laboratory 
Table 1 Non-linear regression coefficients and rate constants for the relationship between percent mass remaining from leaves, stalks, and cobs and extraction time $y=a e^{-k x}$

\begin{tabular}{lllll}
\hline Plant part & Hybrid & $a$ & $k\left(\mathrm{month}^{-1}\right)$ & $\mathrm{r}^{2}$ \\
\hline Leaves & NC+ 4880 & 97.5 & $0.147(0.0111)^{\mathrm{a}}$ & 0.94 \\
& NC+ 4990 Bt & 99.0 & $0.162(0.0224)$ & 0.98 \\
& Pioneer 34N43 & 98.9 & $0.134(0.0233)$ & 0.97 \\
& Pioneer 34N44 Bt & 96.5 & $0.129(0.0129)$ & 0.95 \\
& Mean & & $0.143 \mathrm{a}^{\mathrm{b}}$ & $0.067(0.0031)$ \\
Stalks & NC+ 4880 & 98.4 & $0.055(0.0060)$ & 0.95 \\
& NC+ 4990 Bt & 96.5 & $0.067(0.0078)$ & 0.99 \\
& Pioneer 34N43 & 99.2 & $0.067(0.0073)$ & 0.96 \\
Pioneer 34N44 Bt & 96.2 & $0.064 \mathrm{~b}$ & 0.98 \\
Cobs & Mean & & $0.043(0.0085)$ & 0.94 \\
& NC+ 4880 & 98.1 & $0.035(0.0065)$ & 0.97 \\
& NC+ 4990 Bt & 96.4 & $0.039(0.0059)$ & 0.95 \\
& Pioneer 34N43 & 97.8 & $0.040(0.0063)$ & $0.039 \mathrm{c}$ \\
\hline
\end{tabular}

${ }^{a}$ Values in parentheses are standard errors of the treatment means $(n=4)$

b Mean $k$ values with the same letter are not significantly different at the 0.05 probability level using least significant difference

Table 2 Analysis of variance for effects of independent variables on non-linear regression decomposition constants $(k)$

\begin{tabular}{|c|c|c|c|c|}
\hline ANOVA $^{\mathrm{a}}$ & d.f. & $\mathrm{P}>\mathrm{F}$ & & \\
\hline Hybrid (H) & 3 & 0.6492 & & \\
\hline Plant Part (PP) & 2 & $<0.001$ & & \\
\hline \multirow[t]{3}{*}{$\mathrm{H} \times \mathrm{PP}$} & 6 & 0.0860 & & \\
\hline & & Plant Part & & \\
\hline & & Leaves & Cobs & Stalks \\
\hline \multicolumn{5}{|l|}{ ANOVA $^{\mathrm{b}}$} \\
\hline $\mathrm{Bt}$ & 1 & 0.5080 & 0.9199 & 0.3378 \\
\hline Company $^{\mathrm{c}}$ & 1 & 0.1982 & 0.7101 & 0.1659 \\
\hline Bt $\times$ Company & 1 & 0.5620 & 0.3265 & 0.1618 \\
\hline
\end{tabular}

${ }^{a}$ Analysis of variance for hybrid and plant part main effects and two-way interaction on non-linear regression decomposition constants $(k)$

b Analysis of variance for Bt and company main effects and the two-way interaction for each plant part

c Data from Bt and non-Bt hybrids from the same company combined

studies. The results from our field study where decomposition was measured using a mass loss method did, however, agree with the results reported by Lachnicht et al. (2004) where decomposition rates in the field were not different for Bt and non-Bt cotton plants. The plant part main effect was significant with the highest rate of decomposition for leaves and the lowest rate for cobs (Table 1). The constants ranged from 0.129 month $^{-1}$ to 0.162 month $^{-1}$ for leaves, $0.055 \mathrm{month}^{-1}$ to $0.067 \mathrm{month}^{-1}$ for stalks, and 0.035 month $^{-1}$ to 0.043 month $^{-1}$ for cobs (Table 1).

The total mass of $\mathrm{C}$ and $\mathrm{N}$ remaining in the leaves, cobs, and stalks varied over time but were not different for $\mathrm{Bt}$ and non-Bt and for $\mathrm{NC}+$ and Pioneer hybrids. (Table 3; Fig. 2, 3). Twenty three months after the start of this study $5.5 \%, 38.6 \%$, and $17.7 \%$ 


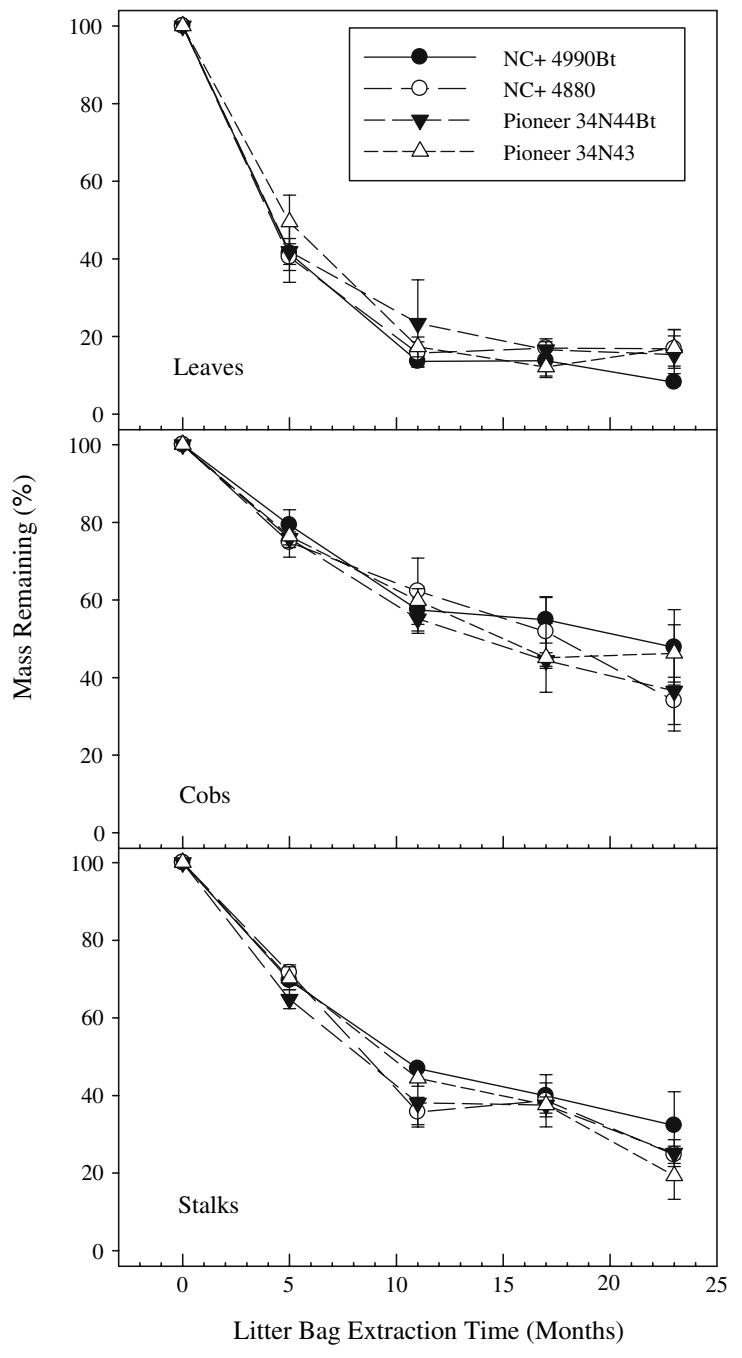

Fig. 1 Percent leaf, cob, and stalk mass remaining at each of five litter bag extraction times for $\mathrm{Bt}$ and non-Bt corn hybrids. Error bars represent the standard error of treatment means

of the total $\mathrm{C}$ mass in leaves, cobs, and stalks from all hybrids remained, respectively. These data follows the pattern of the decomposition rates of the plant parts; leaves lost the greatest amount of $\mathrm{C}$ and cobs the least. The mass of total $\mathrm{N}$ in leaves declined over time. However, a consistent decline of total $\mathrm{N}$ mass over time was not observed for cobs and stalks (Fig. 3). This fluctuation in mass of total $\mathrm{N}$ in cobs and stalks over time was likely a result of variation in factors related to decomposition and $\mathrm{N}$ immobilization in the field. The reduction in the mass of total $\mathrm{C}$ in all plant parts was greater than the reduction in total $\mathrm{N}$ mass after 23 months of decomposition.
Compared to the $\mathrm{C}: \mathrm{N}$ ratios of the initial plant parts, $\mathrm{C}: \mathrm{N}$ ratio for leaves, cobs, and stalks declined by $84.9 \%, 60.1 \%$, and $74.9 \%$ over the 23 month period, respectively (Figs. 2, 3).

The hybrid by plant part interaction effect was significant for total $\mathrm{N}$, all biomass fractions, and the $\mathrm{C}: \mathrm{N}$ ratios of the initial plant residues (Table 4, 5). Much of this interaction was due to the relatively high content of the soluble fraction, low content of hemicellulose and cellulose fractions, and high C:N ratio in Pioneer $34 \mathrm{~N} 44 \mathrm{Bt}$ in the stalks and cobs compared with the other hybrids while these biomass fractions for the leaves varied relatively less across the four hybrids (Table 5). The hybrid by plant part interaction effect for lignin was due to higher a lignin fraction in leaves for the Pioneer $(8.71 \%)$ compared with the NC+ hybrids (7.23\%), but no differences in lignin fractions in cobs and stalks for the four hybrids. The hybrid by plant part interaction effect for total $\mathrm{N}$ was due to higher total $\mathrm{N}$ in stalks for the $\mathrm{NC}+$ hybrids $(0.87 \%)$ compared with the Pioneer hybrids $(0.63 \%)$, but no differences in total $\mathrm{N}$ in leaves and cobs for the four hybrids (Table 5).

Total $\mathrm{C}$, total $\mathrm{N}$, biomass fractions and the $\mathrm{C}: \mathrm{N}$ ratios differed between plant parts (Tables 4,5 ). Of all the plant parts, the leaves had the greatest fraction of their biomass composed of the soluble fraction, and the cobs had the lowest fraction of their biomass composed of the soluble fraction (Table 5). The cobs had the greatest fraction of their biomass composed of the hemicellulose fraction, and the stalks had the lowest fraction of their biomass composed of the hemicellulose (Table 5). The stalks had the greatest fraction of their biomass composed of the cellulose fraction, and the leaves had the lowest fraction of their biomass composed of the cellulose (Table 5). The leaves had the greatest fraction of their biomass composed of the lignin fraction, and the cobs had the lowest fraction of their biomass composed of the lignin fraction (Table 5). The $\mathrm{C}: \mathrm{N}$ ratio was greatest in cobs and least in leaves. The differences in biomass fractions between plant parts likely played a role in differences in rates of decomposition, but other factors important in decomposition were not measured in this study (e.g. residue surface area). The leaves had the highest percent of soluble biomass fraction and lowest $\mathrm{C}: \mathrm{N}$ ratio among plant parts which would favor an increased decomposition rate. However, the leaves also had the highest lignin fraction. 
Table 3 ANOVA for effects of hybrid, plant part, extraction time, Bt status, and company of total C and total $\mathrm{N}$ remaining, and the $\mathrm{C}: \mathrm{N}$ ratio

\begin{tabular}{|c|c|c|c|c|}
\hline & d.f. & Total C & Total N & $\mathrm{C}: \mathrm{N}$ \\
\hline ANOVA $^{\mathrm{a}}$ & & $\mathrm{P}>\mathrm{F}$ & & \\
\hline Hybrid $(\mathrm{H})$ & 3 & 0.4495 & 0.7005 & 0.0539 \\
\hline Plant part (PP) & 2 & 0.0000 & 0.0001 & 0.0000 \\
\hline Extraction time (ET) & 3 & 0.0000 & 0.0225 & 0.0000 \\
\hline $\mathrm{H} \times \mathrm{PP}$ & 6 & 0.5444 & 0.2542 & 0.3351 \\
\hline $\mathrm{H} \times \mathrm{ET}$ & 9 & 0.3111 & 0.0000 & 0.0913 \\
\hline $\mathrm{PP} \times \mathrm{ET}$ & 6 & 0.0148 & 0.4747 & 0.0000 \\
\hline \multicolumn{5}{|l|}{ ANOVA $^{\mathrm{b}}$} \\
\hline Hybrid (Leaves) & 3 & 0.6354 & 0.5603 & 0.3426 \\
\hline $\mathrm{Bt}$ & 1 & 0.4485 & 0.7922 & 0.1193 \\
\hline Company $^{\mathrm{c}}(\mathrm{C})$ & 1 & 0.3092 & 0.1448 & 0.4976 \\
\hline Extraction time (ET) & 3 & 0.0000 & 0.0000 & 0.0000 \\
\hline $\mathrm{Bt} \times \mathrm{C}$ & 1 & 0.6574 & 0.8505 & 0.2773 \\
\hline $\mathrm{ET} \times \mathrm{C}$ & 3 & 0.0550 & 0.1150 & 0.0275 \\
\hline $\mathrm{ET} \times \mathrm{Bt}$ & 3 & 0.7683 & 0.3713 & 0.2088 \\
\hline Hybrid (Cobs) & 3 & 0.7512 & 0.3044 & 0.8638 \\
\hline $\mathrm{Bt}$ & 1 & 0.6614 & 0.6431 & 0.6391 \\
\hline Company (C) & 1 & 0.2601 & 0.0569 & 0.5486 \\
\hline Extraction time (ET) & 3 & 0.0001 & 0.0015 & 0.0000 \\
\hline $\mathrm{Bt} \times \mathrm{C}$ & 1 & 0.9833 & 0.9870 & 0.9100 \\
\hline $\mathrm{ET} \times \mathrm{C}$ & 3 & 0.1658 & 0.1624 & 0.0973 \\
\hline $\mathrm{ET} \times \mathrm{Bt}$ & 3 & 0.4651 & 0.6272 & 0.1773 \\
\hline Hybrid (Stalks) & 3 & 0.1004 & 0.3716 & 0.0172 \\
\hline $\mathrm{Bt}$ & 1 & 0.8554 & 0.9494 & 0.6252 \\
\hline Company (C) & 1 & 0.8183 & 0.1927 & 0.2121 \\
\hline Extraction time (ET) & 3 & 0.0000 & 0.0061 & 0.0000 \\
\hline $\mathrm{Bt} \times \mathrm{C}$ & 1 & 0.0293 & 0.4311 & 0.0033 \\
\hline $\mathrm{ET} \times \mathrm{C}$ & 3 & 0.9058 & 0.3498 & 0.2909 \\
\hline $\mathrm{ET} \times \mathrm{Bt}$ & 3 & 0.9004 & 0.5997 & 0.2983 \\
\hline
\end{tabular}

a Analysis of variance for hybrid, plant part, and extraction time main effects and interactions

b Analysis of variance for overall hybrid effect, and Bt, company, extraction time main effects and interactions for each plant part

c Data from Bt and non-Bt hybrids from the same company

There were some differences in the initial total $\mathrm{C}$, total $\mathrm{N}$, and biomass fractions among the four hybrids, Bt and non Bt hybrids, NC+ and Pioneer companies for each plant part (Table 4). There was also some statistically significant $\mathrm{Bt}$ by company interactions for each plant part. The differences in initial total $\mathrm{C}$, total $\mathrm{N}$, biomass fractions, and $\mathrm{C}: \mathrm{N}$ ratios in this study for each plant part did not cause differences in rates of decomposition or mass of $\mathrm{C}$ remaining between the $\mathrm{Bt}$ and non-Bt hybrids. The differences in initial total $\mathrm{C}$, total $\mathrm{N}$, and biomass fractions between the hybrids are likely related to genetic differences of the hybrids (Barriere et al. 2003; Motavalli et al. 2004; Prior et al. 2004). There were differences in the total $\mathrm{C}$ content, soluble, hemicellulose, cellulose, and lignin fractions of leaves; total $\mathrm{N}$ content, soluble, hemicellulose, cellulose fractions, and the $\mathrm{C}: \mathrm{N}$ ratio of stalks; and soluble and hemicellulose fractions of cobs between the four hybrids (Table 4, 5).

In our study, the differences in the lignin fraction across all four hybrids were $25.3 \%, 16.1 \%$, and 


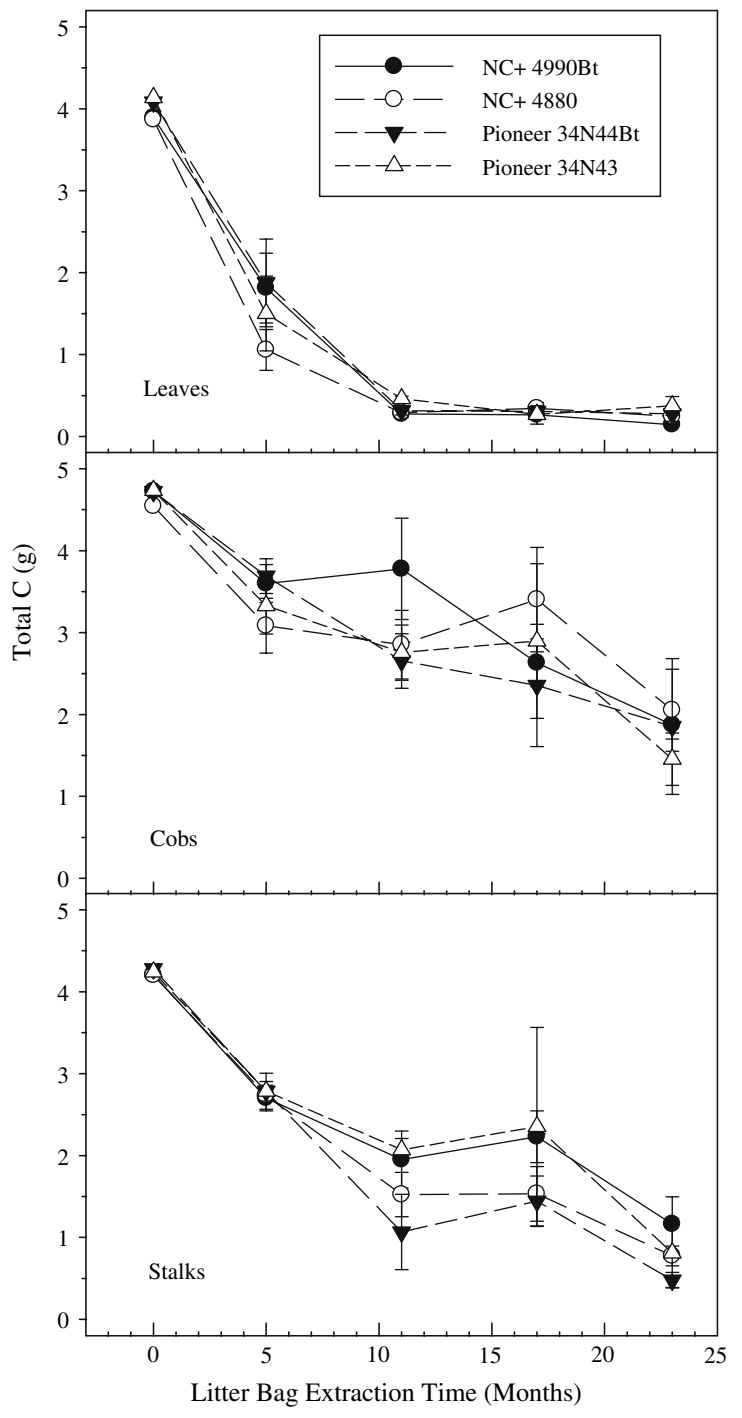

Fig. 2 Total $\mathrm{C}$ in leaf, cob, and stalk samples remaining at each of five litter bag extraction times for Bt and non-Bt corn hybrids. Error bars represent the standard error of treatment means

$26.3 \%$ for leaves, stalks, and cobs, respectively [((highest lignin percent - lowest lignin percent)/ lowest lignin percent) $\times$ 100] (Table 5). In a comparison of nine pairs of isolines, Saxena and Stotsky (2001c) found the lignin content of the Bt hybrids to be $33 \%-97 \%$ higher than for the non-Bt hybrids. In a study by Flores et al. (2005), a mixture of Bt corn leaves and stems had a $96 \%$ higher lignin content than the near-isogenic non-Bt hybrid. Escher et al. (2000), however, found that Bt leaves had lower lignin content than non-Bt leaves. The lack of $\mathrm{Bt}$

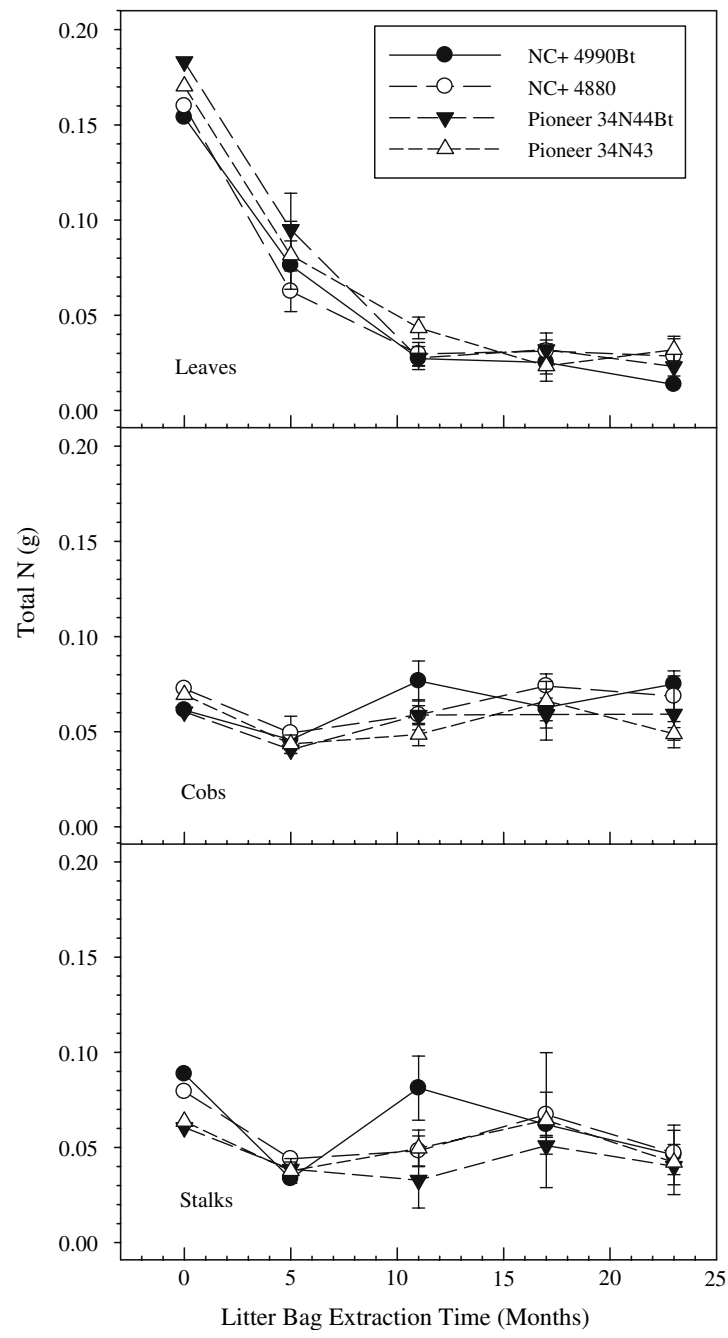

Fig. 3 Total $\mathrm{N}$ in leaf, cob, and stalk samples remaining at each of five litter bag extraction times for $\mathrm{Bt}$ and non-Bt corn hybrids. Error bars represent the standard error of treatment means

effect on the rate of decomposition within each plant part in our study was consistent with the lack of difference in lignin content between the $\mathrm{Bt}$ and nonBt isolines.

The method of lignin determination used by Saxena and Stotzky (2001c) differed from the direct method we used in which acids were used to solubilize and hydrolyze soluble carbohydrates in plant cell walls leaving the lignin which was measured gravimetrically (Van Soest 1982; Hatfield and Fukushima 2005). Saxena and Stotzky (2001c) used the acetyl bromide procedure to completely solubilize 


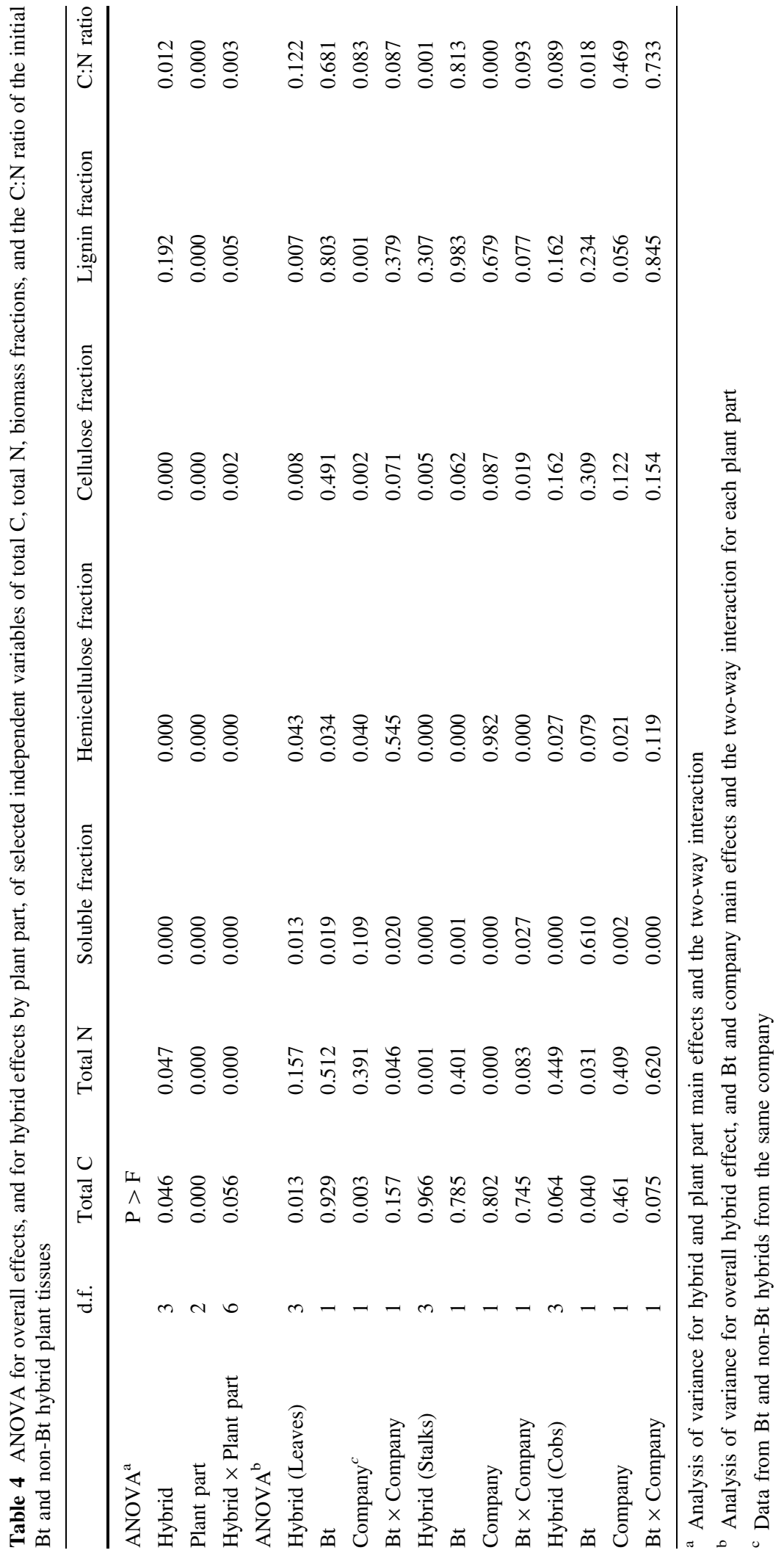




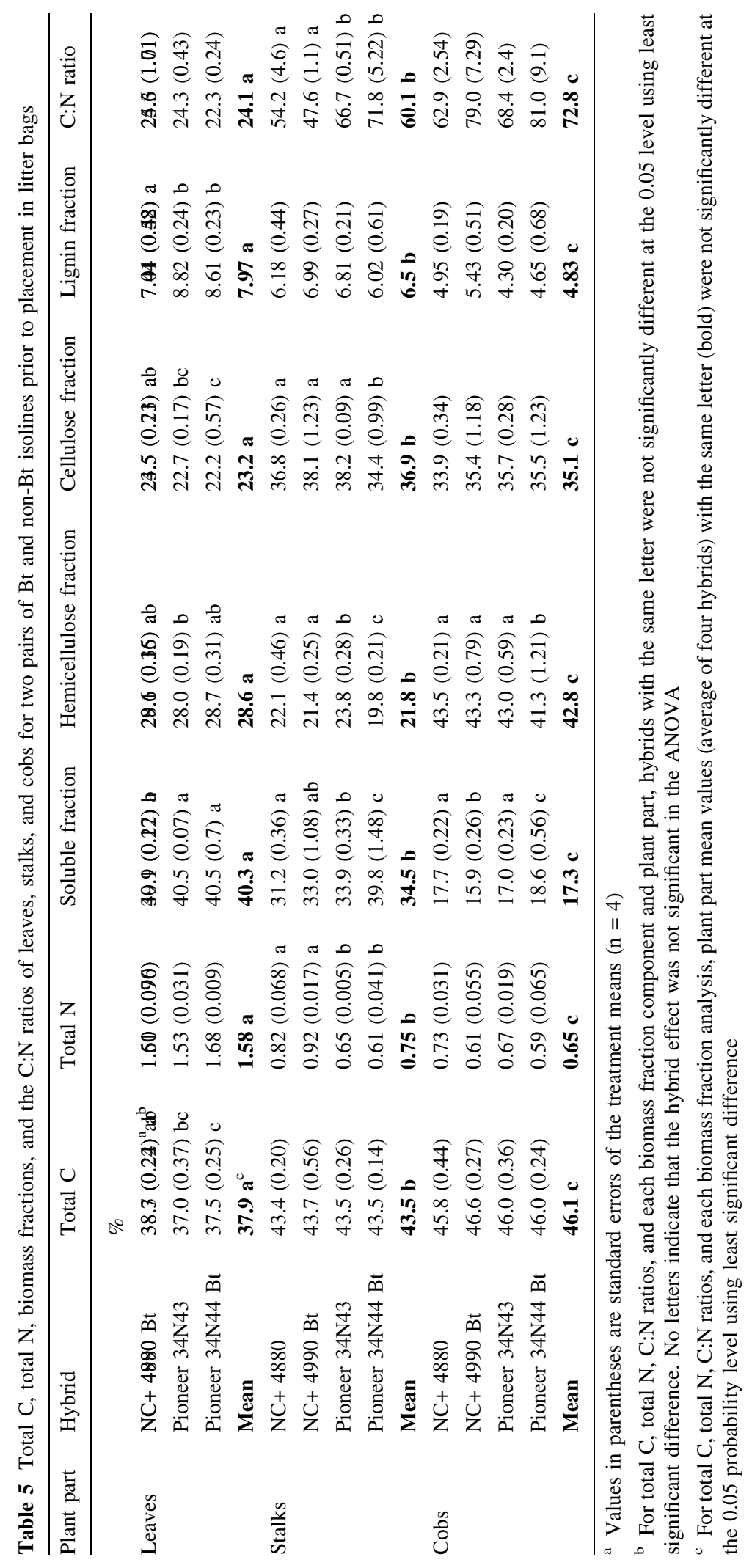


the lignin which was then quantified in solution (Hatfield et al. 1999). In a review of procedures for the determination of lignin, Hatfield and Fukushima (2005) found that different procedures resulted in different estimates of lignin content, that no procedure was superior for accuracy, and advised that the selected procedure be used consistently for all treatments.

\section{Conclusions}

There were no differences in residue decomposition rates or mass of total $\mathrm{C}$ remaining over time between $\mathrm{Bt}$ and non-Bt corn hybrids observed in this field study. Differences in rates of decomposition and biomass fraction contents were observed for leaf, stalk, and cob plant parts. Differences in total C, total $\mathrm{N}$, and biomass fractions of the initial $\mathrm{Bt}$ and non-Bt hybrid plant materials did not correspond to differences in rates of decomposition. These differences are likely related to genetic variation. Based on the results of this study, potential $C$ sequestration should not differ with Bt and non-Bt hybrids. Because of the disparity in research results from published studies, including the one reported here, continued research is needed to help determine the factors that affect the overall and specific effects of Bt transgenic crops on the soil environment.

\section{References}

Analytical Software (2003) Statistix 8. Tallahassee, FL

Barriere Y, Guillet C, Goffner D, Pichon M (2003) Genetic variation and breeding strategies for improved cell wall digestibility in annual forage crops. A review. Anim Res 52:193-228

Blackwood CB, Buyer JS (2004) Soil microbial communities associated with $\mathrm{Bt}$ and non-Bt corn in three soils. J Environ Qual 832-836

Baumgarte S, Tebbe C (2005) Field studies on the environmental fate of the Cry1Ab Bt-toxin produced by transgenic maize (MON810) and its effects on bacterial communities in the maize rhizosphere. Mol Ecol 14:2539-2551

Coyne MS (1999) Soil microbiology: an exploratory approach, 1st edn. Delmar Publishers, Albany, NY

Devare MH, Jones CM, Thies JE (2004) Effect of Cry3Bb transgenic corn and Tefluthrin on the soil microbial community: Biomass, activity, and diversity. J Environ Qual 33:837-843
Escher N, Kach B, Nentwig W (2000) Decomposition of transgenic Bacillus thuringiensis maize by microorganisms and woodlice, Porcellio scaber (Crustacea: Isopoda). Basic Appl Ecol 1:161-169

Flores S, Saxena D, Stotzky G (2005) Transgenic Bt plants decompose less in soil than non-Bt plants. Soil Biol Biochem 37:1073-1082

Hatfield R, Fukushima RS (2005) Can lignin be accurately measured? Crop Sci 45:832-839

Hatfield RD, Grabber J, Ralph J, Brei K (1999) Using the acetyl bromide assay to determine lignin concentration in herbaceous plants: some cautionary notes. J Agri Food Chem 47:628-632

Hopkins DW, Gregorich EG (2003) Detection of decay of the Bt endotoxin in soil from a field trail with genetically modified maize. Euro J Soil Sci 54:793-800

Lal R, Kimble JM, Follett RF, Cole CV (1998) The potential of U.S. cropland to sequester carbon and mitigate the greenhouse effect. Ann Arbor Press, Chelsea MI

Lachnicht SL, Hendrix PF, Potter RL, Coleman DC, Crossley Jr DA (2004) Winter decomposition of transgenic cotton residue in conventional-till and no-till systems. Appl Soil Ecol 27:135-142

Motavalli PP, Kremer RJ, Fang M, Means NE (2004) Impact of genetically modified crops and their management on soil microbially mediated plant nutrient transformations. J Environ Qual 33:816-824

Olsen JS (1963) Energy storage and the balance of producers and decomposers in ecological systems. Ecol 44:322-331

Prior SA, Torbert HA, Runion GB, Rogers HH (2004) Elevated atmospheric $\mathrm{CO}_{2}$ in agroecosystems: residue decomposition in the field. Environ Manage 33:S344-S354

Rissler J, Mellon M (1996) The ecological risk of engineered crops. MIT, Cambridge, MA

Saxena D, Stotzky G (2001a) Bt toxin uptake from soil by plants. Nat Biotechnol 19:199

Saxena D, Stotzky G (2001b) Bacillus thuringiensis (Bt) toxin released from root exudates and biomass of $\mathrm{Bt}$ corn has no apparent effect on earthworms, nematodes, protozoa, bacteria, and fungi in soil. Soil Biol Biochem 33:12251230

Saxena D, Stotzky G (2001c) Bt corn has a higher lignin content than non-Bt corn. Am J Bot 88:1704-1706

Saxena D, Stotzky G (2002) Bt toxin is not taken up from soil or hydroponic culture by corn, carrot, radish, or turnip. Plant Soil 239:165-172

Saxena D, Flores S, Stotzky G (2002) Vertical movement in soil of insecticidal Cry1 Ab protein from Bacillus thuringiensis. Soil Biol Biochem 34:111-120

Saxena D, Stotzky G (2003) Fate and effects in soil of the insecticidal toxins from Bacillus thuringiensis in transgenic plants. In: Collection of Biosafety Reviews. International Centre for Genetic Engineering and Biotechnology, Trieste

Schnepf E, Crickmore N, Van Rie J, Lereclus D, Baum J, Feitelson J, Zeigler DR, Dean DH (1998) Bacillus thuringiensis and its pesticidal crystal proteins. Microbiol Mol Biol Rev 62:775-806

Sims SR, Ream JE (1997) Soil inactivation of the Bacillus thuringiensis subsp. kurstaki CryIIA insecticidal protein 
within transgenic cotton tissue: laboratory microcosms and field studies. J Agric Food Chem 45:1502-1505

Shapiro CA, Ferguson RB, Hergert GW, Dobermann AR, Wortmann CS (2003) Fertilizer suggestions for corn. In: University of Nebraska, NebGuide G74-174-A. Lincoln NE http://www.ianrpubs.unl.edu/epublic/pages/index.jsp?what $=$ publicationD\&publicationId=142. Cited 21 September 2005

Stotzky G (2000) Persistence and biological activity in soil of insecticidal proteins from Bacillus thuringiensis and of bacterial DNA bound on clays and humic acids. J Environ Qual 29:691-705
Van Soest PJ (1982) Nutritional ecology of the ruminant. Cornell University Press, Ithaca, NY

Wei-xiang W, Qing-Fu Y, Hang M, Xue-jun D, Wen-ming J (2004) Bt-transgenic rice straw affects the culturable microbiota and dehydrogenase and phosphatase activities in flooded paddy soil. Soil Biol Biochem 36:289-295

Zwahlen C, Hilbeck A, Howald R, Nentwig W (2003) Effects of transgenic Bt corn litter on the earthworm Lumbricus terrestris. Mol Ecol 12:1077-1086 